Jaroslaw Klaczkow

\title{
Udzial młodzieży luterańskiej w życiu akademickim II Rzeczypospolitej
}

\section{Ośrodki akademickie i miejsca studiowania}

Kościół Ewangelicko-Augsburski w II Rzeczypospolitej nie posiadał własnej wyższej uczelni. Jej namiastką stało się utworzenie w dniu 4 stycznia 1919 r., na mocy decyzji Senatu Uniwersytetu Warszawskiego, Wydziału Teologii Ewangelickiej. Zajęcia rozpoczęły się oficjalnie w dniu 4 stycznia 1921 r. Natomiast formalne zatwierdzenie działalności przez Ministerstwo Wyznań Religijnych i Oświecenia Publicznego nastapiło dopiero 19 kwietnia $1922 \mathrm{r}^{1}$

Od samego początku funkcjonowania władze zwierzchnie Wydziału, w osobach księży profesorów Józefa Szerudy i Edmunda Burschego (brata przyrodniego zwierzchnika Kościoła Ewangelicko-Augsburskiego biskupa Juliusza Bursche), widziały w nim miejsce dla wszystkich ewangelików bez względu na przynależność kościelną. Nie znajdowało to początkowo zbyt głośnego echa, np.: warszawski Kościół Ewangelicko-Reformowany zażądał od Sejmu w dniu 22 grudnia 1920 r. utworzenia własnego wydziału, jakby zapominając o szczupłej liczbie swoich wiernych ${ }^{2}$. Z kolei Kościół Ewangelicko-Unijny obawiając się polonizacji swych teologów zdecydowanie odrzucił możliwość ich tam stu-

1 „Zwiastun Ewangeliczny”, nr 19, 12 V 1929, s. 165-166; por też. J. Gryniakow, Ekumeniczne dqżenia protestantyzmu polskiego od traktatu warszawskiego 1767/68 do II wojny światowej, Warszawa 1972, s. 78.

2 J. Gryniakow, op. cit., s. 79. 
diowania i utworzył w dniu 11 października 1920 r. własne Seminarium teologiczne w Poznaniu (Ewangelisches Predigerseminar).

Początkowa nieufność i uprzedzenia $z$ biegiem czasu minęły i na Wydziale Teologii Ewangelickiej stopień magistra teologii ewangelickiej zdobywali również przedstawiciele innych Kościołów, poza luterańskim. Studiowali tu $\mathrm{m}$. in. przedstawiciele obydwu Kościołów kalwińskich, metodyści, baptyści oraz członkowie „poznańskiego” Kościoła Ewangelicko - Unijnego. Jak podaje ks. Jerzy Gryniakow: „W roku akademickim 1934/35 zapisanych było na wydziale już 102 studentów. $80 \mathrm{z}$ Kościoła Ewangelicko - Augsburskiego (w tym jedna studentka i dwóch wolnych słuchaczy), dwóch z poznańskiego Kościoła Unijnego, czterech z Kościoła Ewangelicko - Reformowanego w Warszawie, jeden $\mathrm{z}$ Kościoła Ewangelicko - Reformowanego w Wilnie, 11 z Kościoła Ewangelickiego Augsburskiego i Helweckiego Wyznania w Małopolsce, dwóch ze Śląska czeskiego, jeden z Kościoła Metodystów, jeden z Kościoła Baptystów"3. W sumie przez cały okres międzywojenny mury Wydziału ukończyło 168 magistrów teologii ewangelickiej. Nie jest to liczba zbyt wysoka, jeśli się weźmie pod uwagę fakt, że na uczelnię co roku wstępowało ok. 40 osób. Przyczyną takiego stanu rzeczy był $\mathrm{m}$. in. fakt bardzo wysokiego poziomu na Wydziale, któremu mogli sprostać tylko najlepsi.

Niebagatelną też rolę odgrywała polityka dziekańska, która starała się tak kierować sprawami kadrowymi, aby kończący studia mieli od razu możliwość pracy w parafiach, gdzie nie było zbyt wielu miejsc, szczególnie w dobie Wielkiego Kryzysu.

W przypadku pochodzenia narodowego studentów teologii można dojść do wniosku, że większość z nich reprezentowała narodowość polska, np.: w roku akademickim 1926/27 liczba studentów Wydziału Teologii Ewangelickiej wynosiła 58 osób, z czego do używania języka polskiego przyznawało się 43 osoby, do niemieckiego 13 a do innych dwie ${ }^{4}$.

Przeważająca ilość studentów, w omawianym roku 1926/27, pochodziła $\mathrm{z}$ terenów dawnego Królestwa Kongresowego (45 osób), następ-

${ }^{3}$ Cyt. za J. Gryniakow, op. cit., s. 81.

${ }^{4}$ „Zwiastun Ewangeliczny”, nr 14, 3 IV 1927, s. 103. 
nie z Zaolzia ( 9 osób), Małopolski (3 osoby) oraz Kresów Wschodnich $(1 \text { osoba })^{5}$. Do wyznania ewangelicko-augsburskiego przyznawało się 52 badanych, ewangelicko-reformowanego pięciu, natomiast do anglikańskiego jedna. Przynależność państwową polską deklarowało $51 \mathrm{z}$ nich, zaś czechosłowacką siedmiu'.

Poza Wydziałem Teologii Ewangelickiej, studenci protestanccy pobierali naukę we wszystkich polskich uczelniach, nie wyłączając nawet Katolickiego Uniwersytetu Lubelskiego.

W roku akademickim 1933/34 studiowało ogółem na Uniwersytecie Warszawskim 9158 studentów, z czego 68,5\% stanowili rzymsko-katolicy, 0,3\% greko-katolicy, 3,7\% ewangelicy, 3,1\% prawosławni i 23,8\% wyznawcy religii mojżeszowej ${ }^{7}$.

Zupełnie inaczej proporcje te wyglądały na Politechnice Warszawskiej. Studiowało tam w tym samym czasie 4316 studentów, z których $83,6 \%$ było wyznania rzymsko-katolickiego, 2,8\% ewangelickich, 3\% stanowili prawosławni oraz $10,2 \%$ mojżeszowi ${ }^{8}$.

W cytowanych danych widoczna jest nadreprezentacja Żydów (szczególnie na medycynie i na prawie). Ewangelicy wykraczali poza statystyczną ogólnopolską jedynie w Krakowie.

W najstarszym ośrodku akademickim kraju, tj. na Uniwersytecie Jagiellońskim we wspomnianym okresie studentami było 7144 osób, z czego 67,1\% należało do Kościoła rzymskokatolickiego, 5\% do Cerkwie unickiej, $14 \%$ do Kościołów protestanckich, zaś $26 \%$ uczęszczało do synagog ${ }^{9}$.

Trochę inne proporcje występowały na Kresach Wschodnich. Na uniwersytecie wileńskim liczba studentów wynosiła 3618 osób. 59\% stanowili katolicy, 8,4\% prawosławni, 1,3\% ewangelicy, a starozakonni 29,7\%. Z kolei we Lwowie na uniwersytecie Jana Kazimierza miało indeksy 6276 osób. Blisko połowę $(49,4 \%$ ) stanowili rzymscy katolicy, $5 \%$ unici, $1,4 \%$ protestanci i $26 \%$ wyznawcy religii żydowskiej ${ }^{10}$. Ogólną

\footnotetext{
${ }^{5}$ Ibidem, s. 103.

${ }^{6}$ Ibidem,

${ }^{7}$ Ibidem, nr 17, 29 IV 1934, s. 132.

${ }^{8}$ Ibidem.

${ }^{9}$ Ibidem.

${ }^{10}$ Ibidem.
} 
liczbę studiujących ewangelików obrazuje poniższa tabela.

Tabela 1. Liczba studentów ewangelików na polskich uczelniach w okresie dwudziestolecia międzywojennego

\begin{tabular}{|c|c|}
\hline $\begin{array}{c}\text { rok } \\
\text { akademicki }\end{array}$ & $\begin{array}{l}\text { liczba studentów wyznania } \\
\text { ewangelicko-augsburskiego }\end{array}$ \\
\hline 1918-1922 & brak danych \\
\hline $1922 / 23$ & 607 \\
\hline $1923 / 24$ & 621 \\
\hline $1924 / 25$ & brak danych \\
\hline $1925 / 26$ & 819 \\
\hline $1926 / 27$ & 902 \\
\hline $1927 / 28$ & 902 \\
\hline $1928 / 29$ & 1027 \\
\hline $1929 / 30$ & 1106 \\
\hline $1932 / 33$ & 1360 \\
\hline $1933 / 34$ & 1303 \\
\hline $1934 / 35$ & 1285 \\
\hline $1935 / 36$ & 1315 \\
\hline 1937-1939 & brak danych \\
\hline
\end{tabular}

•ródło: „Zwiastun Ewangeliczny” nr 13 z 31 XII 1929, s. 117 (dane z lat 1922/23, 1925/26, 1927/29); nr 3 z 20 I 1935, s. 16-17 (dane z lat 1923/24, 1926/27, 1929/30, 1932/33, 1933/34); nr 16 z 20 IV 1930, s. 130 (dane z lat 1928/29); „Przegląd Ewangelicki" nr 6 z 16 XII 1937, s. 54 (lata 1934/35, 1935/36).

Można więc zauważyć tendencję rosnącą (choć nie bez załamań), zbliżoną do liczby 1300 osób. W porównaniu z innymi grupami wyznaniowymi była to mała społeczność, ale znajdowała swoje uzasadnienie również w stosunkowo niewielkiej liczebności protestantów w Polsce (ok. 2,6\% w latach trzydziestych). Liczba ta była więc niejako odzwierciedleniem ogólnego trendu demograficznego wśród ludności wyznania ewangelickiego.

Najwięcej studentów wyznania protestanckiego gromadził Uniwersytet Warszawski, w którym w roku akademickim 1932/33 przebywało 
679 osób. W następnej kolejności znajdowały się: Uniwersytet im. Adama Mickiewicza (265); Uniwersytet im. Jana Kazimierza we Lwowie (171); Uniwersytet Stefana Batorego (66); Wolna Wszechnica Polska w Łodzi (19); Katolicki Uniwersytet Lubelski (7). Na tej ostatniej uczelni ewangelicy uczęszczali na Wydziały Humanistyczny oraz Prawa i Nauk Ekonomiczno-Społecznych ${ }^{11}$.

Statystycznie (biorąc pod uwagę liczbę danej ludności w skali całego kraju) największą grupę studentów stanowili wyznawcy religii mojżeszowej, następni byli rzymscy katolicy, ewangelicy, greko-katolicy oraz prawosławni ${ }^{12}$.

Mimo, że najwięcej ewangelickich studentów grupowała Warszawa (ok. 3,7\%), to procentowo, w porównaniu $\mathrm{z}$ innymi konfesjami, najwyższa ilość protestantów znajdowała się na Uniwersytecie Jagiellońskim $(14 \% \text { ogółu })^{13}$.

Największą popularnością wśród ewangelików w roku akademickim 1932/33 cieszyły się wśród studiujących kierunki humanistyczne: filozofia (432 osoby), prawo (240). Zaraz po nich sporą liczbę adeptów zebrał handel (142) i medycyna (107 ewangelików). Z kolei teologię ewangelicką studiowało 93 studentów; nauki techniczne i elektrotechnikę 89. Najmniejszą popularnością cieszyło się rolnictwo. Jego arkana zgłębiało tylko 59 osób. Inne nauki jak choćby: farmaceutyka, weterynaria, chemia, miernictwo czy górnictwo miały poniżej 50 słuchaczy ${ }^{14}$.

Podsumowując, można stwierdzić, że ewangelicy w stosunku do innych wyznań wykazywali się największą procentowo liczbą studiujących teologię. Tak zdecydowana przewaga, wynikała przede wszystkim z faktu że w Kościołach ewangelickich wszyscy późniejsi duchowni musieli mieć ukończone studia wyższe, podczas gdy w innych wyznaniach nie wymagano tego jako sine qua non późniejszej pracy w parafiach.

\footnotetext{
"Ibidem, nr 29, 16 VII 1933, s. 215.

${ }^{12}$ Ibidem, nr 48, 2 XII 1934, s. 380.

${ }^{13}$ Ibidem, nr 17, 29 IV 1934, s. 112.

${ }^{14}$ Ibidem, nr 48, 2 XII 1934, s. 380.
} 


\section{Przynależność do organizacji studenckich}

Młodzież protestancka w przeważającej mierze należała do ogólnouczelnianych związków i zrzeszeń studenckich, często w „morzu” katolickim nie akcentując swego wyznania ${ }^{15}$. Prowadziło to nieraz to konwersji na rzymski katolicyzm. Aby zaradzić temu zjawisku na uczelniach zaczęły powstawać konfesyjne związki akademickie, gromadzace ewangelików. Inicjatywa wyszła od prof. Wydziału Teologii Ewangelickiej Józefa Szerudy, aczkolwiek już wcześniej powstawały różnego typu pomysły. Jednym z nich, autorstwa dr W. J. Rose, było powołanie przy Społeczności Chrześcijańskiej ${ }^{16}$ (istniejącej w ramach zboru warszawskiego) utworzył małe kółko gromadzące głównie studentów teologii. Miało ono charakter religijno-etyczny. Zebrania odbywały się raz na tydzień w niedzielę, na godzinę przed zebraniem Społeczności. Były poświęcone na studia biblijne oraz poruszały różne aspekty życia kościelnego. Nie była to jednak jeszcze studencka organizacja z prawdziwego zdarzenia.

Najpoważniejszym i najbardziej znanym okazała się działająca w Warszawie od maja 1926 r. „Filadelfia”. W swej dhugoletniej działalności starała się ona przeciwstawić wspomnianym wcześniej, niepokojącym dla przyszłości ewangelicyzmu, tendencjom, a nawet rozwinąć ofensywne skrzydła. Jeden z jego twórców, Adolf Szmidt, w następujący sposób przedstawiał, kilka lat później, potrzebę jego istnienia: „«Naszym ideałem jest Chrystus» - to jest rozwiazanie wszelkich problemów religijnych i moralnych gnębiących dzisiejszego człowieka. Dlatego też można obserwować nawrót do religii. Czy my akademiccyewangelicy staniemy na uboczu? Przecież możemy do naszego społeczeństwa wnieść dużo pozytywnych wartości, którymi katolicyzm przewyższamy. Jeżeli tego nie dokonamy to nie wiem, w jaki sposób utrzy-

\footnotetext{
${ }^{15}$ Nic więc dziwnego, że kilka lat później w jednym z numerów tygodnika ks. Zygmunta Michelisa znalazła się następująca uwaga: „Założenie Koła Studentów Ewangelików „Filadelfia” było wystapienie przeciw fałszywemu stanowisku młodego ewangelika, wstydzącego się własnego wyznania wobec większości katolickiej”, [w:] ,Zwiastun Ewangeliczny", nr 16, 20 IV 1930, s. 128.

${ }^{16}$ Była to swego rodzaju organizacja interprotestancka gromadząca ewangelików augsburskich, reformowanych i unijnych.
} 
mamy się w otaczającym nas morzu katolicyzmu. W poczuciu więc odpowiedzialności, jaka na nas obecnie spada, musimy w czasie studiów naszych zrobić wszystko, aby w przyszłości godnie nosić miano twórczego ewangelika, a nie protestanta tylko. Zrzeszajmy się więc w Akademickich Kołach Ewangelickich i pracujmy jak najusilniej nad nami samymi w duchu etyki Chrystusowej"17.

Głównym współtwórcą i późniejszym duchownym opiekunem „Filadelfii" był ks. Józef Szeruda, który przy Społeczności Chrześcijańskiej utworzył nowe koło grupujące młodych ludzi, mające charakter religijno-etyczny, do którego wprowadził głównie studentów teologii.

Zebrania odbywały się co tydzień, na które przychodziło za każdym razem coraz więcej ludzi. Postanowiono więc utworzyć większą organizację. Zbierano adresy wszystkich studentów ewangelików zamieszkałych w Warszawie, co pozwoliło w maju 1926 r. zwołać zebranie, na którym wyłoniono tzw. „Komitet Siedmiu” mający się zająć sprawami organizacyjnymi i opracowaniem statutu.

W dniu 12 grudnia 1926 r. odbyło się pierwsze walne zgromadzenie, które wyłoniło zarząd Koła. Na jego czele stanął student Wydziału Nauk Przyrodniczych Uniwersytetu Warszawskiego Eryk Hauptmann, zaś sekretarzem student teologii Jerzy Cymorek. Powstały trzy sekcje:

a) religijno-etyczna (urządzająca zebrania biblijne i odczyty referatowe profesorów teologii),

b) społeczna (organizująca wykłady znanych działaczy społecznych, oraz lekcje dla konfirmantów-analfabetów),

c) towarzyska (urządzająca zebrania towarzyskie, składające się ze śpiewu, deklamacji; organizowano również wycieczki i różnego typu imprezy).

Pierwsza z nich spotykała się zawsze w czwartki. Podczas tych posiedzeń czytano, m. in. dzieła Förstera „Religia a kształcenie charakteru”, „Chrystus a życie ludzkie”.

Z kolei członkowie sekcji społecznej zbierali się we wtorki, aby referować tematy z różnych dziedzin opieki społecznej, np. „Opieka nad matką i dzieckiem”, „Sądy dla nieletnich”. Oprócz tego członkowie przeprowadzali szereg wywiadów z ludźmi znajdującymi się w trudnej sy-

${ }^{17}$ „Zwiastun Ewangeliczny”, nr 2, 10 I 1932, s. 14. 
tuacji materialnej. Początkowo był to Ewangelicki Komitet Pomocy Bezrobotnym, aby następnie przekształcić się w Obywatelski Komitet Opieki Społecznej. Wywiadów w latach Wielkiego Kryzysu sekcja przeprowadziła ponad $400^{18}$.

Ostatnia sekcja urządzała raz w miesiącu ,herbatki” połączone z tańcami. Przychodziło na nie średnio 100 osób $^{19}$. „Filadelfia” posiadała również własny chór.

Zebrania wszystkich sekcji odbywały się początkowo w pomieszczeniach seminaryjnych Wydziału Teologii Ewangelickiej UW. Oprócz działalności w sekcjach „Filadelfiä” organizowała Zebrania Ogólne w gmachu gimnazjum im. Mikołaja Reja. Podczas jednego z nich w dniu 22 listopada 1932 r. referat pt. „Wskazania programowe” wygłosił dyrektor szkoły Adolf Rondthaler. Natomiast tydzień później jedna z członkiń Koła E. Brychówna podzieliła się wrażeniami z wycieczki do Angliii $^{20}$.

Delegaci Koła uczestniczyli także w różnego typu zjazdach, np.: w Bystrzycy n/Olzą (Zaolzie), w Zjeździe Młodzieży Ewangelickiej, w Zjeździe Polskich Zborów i Towarzystw Ewangelickich w Państwie Polskim w Cieszynie oraz w obradach Rady Pacyfistycznej ${ }^{21}$.

Koło organizowało również Wieczór Studenta Ewangelika, który przyniósł 2 tysiące złotych dochodu. Środki te wykorzystano następnie na pożyczki dla studentów ${ }^{22}$.

Oficjalna legalizacja i rejestracja nastapiła dopiero w dniu 18 listopada 1927 r. Nowym zarządem kierował wtedy już Jerzy Cymorek. Organizacja nazywała się od tego czasu „Koło Studentów Ewangelików «Filadelfia» i zrzeszała młodzież akademicką ze wszystkich uczelni warszawskich. W dniu 4 grudnia 1927 r. przystapiło ono do Zwiąku Polskich Zborów i Towarzystw Ewangelickich w Państwie Polskim. «Filadelfia» jako jednostka prawna mogła rozporządzać majątkiem, nabywać oraz zbywać nieruchomości. W związku z tym faktem miała bardzo szerokie plany. Chciała, m. in. wybudować Dom Zdrowia, co

\footnotetext{
${ }^{18}$ Ibidem.

${ }^{19}$ Tbidem.

${ }^{20}$ Ibidem, nr 2, 10 I 1932, s. 15.

${ }^{21}$ Ibidem, nr 11, 11 III 1928, s. 85-86.

${ }^{22}$ Ibidem, nr 16, 18 IV 1937, s. 146-147.
} 
jednak nie udało się ze względów finansowych. «Filadelfii» powiodło się natomiast zorganizowanie kolonii letnich na Śląsku Cieszyńskim. Mogli w nich brać również udział ewangeliccy studenci z innych polskich uczelni. W tym czasie w ramach organizacji powołano również do. życia komisję prasową (informowała ewangelickich studentów o pracach „Filadelfii”), kółko muzyczne, sekcje dramatyczne i artystyczne. Rozpoczęto również zbiórkę książek do powstającej biblioteki.

W roku 1930 delegaci „Filadelfii” wzięli udział w uroczystościach nadawania doktoratu, przez Wydział Teologii Ewangelickiej, biskupowi Kościoła Ewangelicko-Augsburskiego ks. dr Juliuszowi Burschemu obdarzając go jednocześnie tytułem członka honorowego organizacji ${ }^{23}$ (dwa lata później tytuł członka honorowego otrzymała Maria [Malina] Bursche - wnuczka biskupa). W sierpniu tego samego roku odbył się zjazd delegatów Akademickich Kół Ewangelickich. Poruszono tam, m. in. potrzebę zorganizowania jednej ogólnopolskiej organizacji studenckiej grupującej wszystkich studentów. Pozostało to jednak jedynie w sferze planów. Skupiono się w związku z tym na rozbudowie poszczególnych sekcji. Na przykład członkowie sekcji społecznej podjęli współpracę z Obywatelskim Komitetem Pomocy Społecznej. Do ich zadań należało, wspomniane już wcześniej, m. in. przeprowadzanie wywiadów środowiskowych wśród warszawskich bezrobotnych. Dla dzieci $z$ tej grupy społecznej przeznaczono też $50 \%$ dochodu pochodzącego $\mathrm{z}$ wieczoru muzycznego zorganizowanego w roku akademickim 1932/193324. Pozostała część skierowana została na fundusz pożyczkowy KSE „Filadelfia”. W pierwszych latach działalności starano się również o utrzymywanie szerokich kontaktów z Kołem Teologów Ewangelickich UW oraz z Towarzystwem Polskiej Młodzieży Ewangelickiej. Nawiązano również łączność ze studencką organizacją „Znicz”. Grupowała ona studiujących w Warszawie Ślązaków.

W dniu 15 marca 1931 r. na Nadzwyczajnym Walnym Zebraniu Koła Studentów Ewangelików „Filadelfia” wybrano nowe władze na kolejną kadencję. Prezesem został Adolf Schmidt. Zastępcami zostali M. Brokopówna (I wice - prezes) oraz cieszyniak Paweł Bocek (II wice- pre-

\footnotetext{
${ }^{23}$ Ibidem.

${ }^{24}$ Ibidem.
} 
zes). Funkcję sekretarza powierzono K. Klusowi ze Śląska Cieszyńskiego, natomiast jego zastępcą została Patzakówna. Dokonano też wyboru skarbnika i jego zastępcy. Zostali nimi W. Sommer oraz I. Lukomska ${ }^{25}$.

Kolejną elekcję przeprowadzono w dniu 25 października 1932. Zorganizowano kolejne zebranie wyborcze. Prezesem wybrano ponownie Adolfa Schmidta. Jego pierwszym zastępcą została ponownie M. Brokopówna. Pozostały skład zarządu kształtował się następująco: M. Wałach (II wice - prezes), S. Jeute (sekretarz), I. Łukomska (zastępca sekretarza), W. Kornhöfer (skarbnik), W. Klepper (pomocnik skarbnika). Wybrano również nowe władze Sekcji Społecznej i Towarzyskiej. Na czele pierwszej stanęła Wanda Rondthalerówna, druga znalazła się w ręku K. Wolschendorf ${ }^{26}$. Na zakończenie obrad podjęto jeszcze uchwałę, wskazującą za celowe zwołanie, w czasie Zielonych Świątek 1933 r., zjazdu byłych członków Koła «Filadelfia». „Filadelfia zorganizowała jeszcze w roku 1932 dwa spotkania. Pierwsze w dniu 8 grudnia miało charakter nadzwyczajnego Walnego Zebrania Delegatów. Dyskutowano na nim sprawę deklaracji ideowej organizacji. Uchwały jednak nie udało się przyjąć z powodu zbyt rozbieżnych zdań na jej temat.

Pięć dni później odbyło się święto Koła połączone z Wieczorem Wigilijnym. Dokonano na nim uroczystego przyjęcia w poczet członków wszystkich, którzy wstapili w bieżącym roku do $\mathrm{Koła}^{27}$.

W związku z nową „Ustawą o stowarzyszeniach akademickich” z 30 kwietnia 1933 r., nie zezwalającą na istnienie organizacji o charakterze międzyuczelnianym, KSE „Filadelfia” czyniła starania w Ministerstwie Wyznań Religijnych i Oświecenia Publicznego (MWRiOP) i w MSW aby w drodze wyjątku -jako organizacja wyznaniowa - mogła dalej funkcjonować w dotychczasowym kształcie. Gdy wysiłki te zakończyły się niepowodzeniem konieczna stała się zmiana statutu i w lutym 1934 r. powołano do życia nową jednouczelnianą organizację o nazwie „Koło Studentów Ewangelików Uniwersytetu Warszawskiego „Filadelfia”. Została ona zarejestrowana w dniu 28 lutego 1934 r. przez Senat UW. Studenci z takich uczelni jak Politechnika Warszawska, Szkoła Główna Go-

\footnotetext{
${ }^{25}$ Ibidem, nr 13, 29 III 1931, s. 32.

${ }^{26}$ Ibidem, nr 16, 18 IV 1937, s. 146-147

${ }^{27}$ Ibidem.
} 
spodarstwa Wiejskiego, Szkoła Nauk Politycznych zostali wykreśleni z listy członków.

Organizacja skurczyła się jedynie do studentów UW. W związku z tym konieczne stało się zwołanie nowego Walnego Zebrania. Zorganizowano je w dniu 11 marca 1934 r. Na wstępie dotychczasowy kurator Koła ks. prof. Józef Szeruda udzielił absolutorium ustępującemu zarządowi, poczym przystapiono do wyboru nowych władz. Prezesem wybrano Ryszarda Trenklera ${ }^{28}$, a jego zastępcą Edward Dietza ${ }^{29}$. Skład zarządu uzupełnili ponadto: Engelhardt Radke (skarbnik), J. Golianówna (sekretarz) i Jolanta Rosnagelówna (członek zarządu). Ponadto zebrani delegaci powołali nowych kierowników sekcji religijno - etycznej, społecznej i towarzyskiej. Zostali nimi w kolejności Gustaw Meyer, Halina Hoffmanówna, Zenon Dietrich ${ }^{30}$.

W związku ze zmianami organizacyjnymi wymyślono nową deklarację członkowską. Brzmiała ona w sposób następujący: „Ja student wyznania ewangelickiego, chcę służyć idei ewangelicyzmu i sumiennie wypełniać moje obowiązki akademickie. Jako ewangelik chcę kształtować mój pogląd na świat w duchu postępu religijnego i równouprawnienia, w życiu postępować zgodnie z własnym sumieniem, w myśl wskazań Chrystusowych. Jako student chcę rozszerzyć swoje horyzonty myślenia i swój zakres poznania, chcę zdobyć przygotowanie do przyszłej swej pracy zawodowej. Wstępuję do „Filadelfii”, aby przez wspólną pracę samowychowawczą i samokształceniową nad sobą w gronie kolegów, studentów ewangelików, stać się uświadomionym ewangelickim pracownikiem na niwie ewangelickiej w Polsce w myśl wskazań naszych przywódców duchowych, aby stać się lepszym człowiekiem oraz

\footnotetext{
${ }^{28}$ Ryszard Trenkler po ukończeniu studiów teologicznych został ordynowany przez biskupa Juliusza Burschego na urząd duchownego Kościoła Ewangelicko-Augsburskiego. Po II wojnie światowej pełnił szereg funkcji kościelnych, m. in. ks. pastora parafii toruńskiej, bydgoskiej, aby na koniec objąć urząd I proboszcza zboru św. Trójcy w Warszawie. Część rodziny mieszka do dziś dnia w Toruniu.

${ }^{29}$ Po ukończeniu Wydziału Teologii Ewangelickiej został ordynowany przez biskupa Juliusza Burschego, na urząd duchownego Kościoła Ewangelicko-Augsburskiego. Po II wojnie światowej pełnił, $m$. in. stanowisko proboszcza parafii ewangelickiej $\mathbf{w}$ Trójmieście.

${ }^{30}$, ,Zwiastun Ewangeliczny” nr 11, 18 III 1934, s. 82.
} 
poważniejszym studentem obecnie a sumiennym fachowcem później”31.

Zmiana nie przyniosła w pierwszym okresie nic dobrego i przyczyniła się do jeszcze większych problemów kadrowych organizacji, do której już wcześniej należało zaledwie $10 \%$ studiującej w Warszawie młodzieży ewangelickiej. W roku akademickim 1934/35 do KSE „Filadelfia" należało 95 osób, z czego 45\% stanowiły kobiety.

Największą ilość członków „Filadelfii” gromadził Wydział Humanistyczny (40\%), następny był Wydział Teologii Ewangelickiej (31\%), Wydział Matematyczno - Przyrodniczy (8\%), Wydział Prawny (8\%), Wydział Weterynaryjny (5\%), Wydział Medyczny (4\%), Wydział Farmaceutyczny $(4 \%)^{32}$.

Liczba 95 studentów nie była jednak, jak na ówczesne stosunki na wyższych uczelniach, zbyt imponująca. Aby zaradzić tym niezbyt optymistycznym trendom w 1935 r., w porozumieniu z kuratorem Koła ks. prof. Józefem Szeruda, zmieniono znów statut i zarejestrowano przy komisariacie rządu miasta st. Warszawy „Stowarzyszenie Młodzieży Ewangelickiej „Filadelfia”. Przejmowało ono idee i tradycje dawnej organizacji. Zachowano też wszystkie te punkty dawnego statutu, które nie kolidowały z przepisami nowej ustawy. Rozszerzono jednak znacznie kryteria przyjęcia. Do nowej „Filadelfii” mogli się zapisać nie tylko studenci, ale również osoby posiadające ,małą maturę”, tj. 6 klas gimnazjum starego typu. Spowodowało to zwiększenie się liczby członków „Filadelfii”, która według jednego z jej członków wynosić miała w roku 1937 - 340 osób i gromadziła ok. $25 \%$ młodzieży ewangelickiej studiującej w Warszawie. Spadł procentowy udział teologów, stanowili oni jedynie $8 \%$ ogólnej liczby członków ${ }^{33}$.

Powstało aż 12 sekcji wewnętrznych. Schemat poszczególnych posiedzeń przedstawiał się w sposób następujący. W poniedziałek wygłaszano referat $z$ dziedziny społecznej, we wtorek $-z$ dziedziny zawodowej, w środę odbywały się zebrania towarzyskie, w czwartek - spotkania biblijne, $w$ piątek referat $\mathrm{z}$ dziedziny religii, $\mathrm{w}$ sobotę referat $\mathrm{z}$ dziedziny etyki i filozofii. Raz w miesiącu „Filadelfia” wynajmowała salę

\footnotetext{
${ }^{31}$ Ibidem, nr 40, 7 X 1934, s. 316.

32 Ibidem, nr 48, 2 XII 1934, s. 381.

${ }^{33}$ Ibidem, nr 11, 14 III 1937, s. 97.
} 
kina „Kultura” i przeprowadzała tam zebrania. Poświęcone były one przede wszystkim omówieniu wszystkich zaszłych w międzyczasie wydarzeń społecznych, politycznych i kulturalnych. Starano się również podkreślać rolę ewangelicyzmu w Polsce i na świecie ${ }^{34}$.

Rozszerzenie oferty do wszystkich grup młodzieży ewangelickiej wywołało jednak również głosy krytyczne. Pochodziły one przede wszystkim z kręgów Towarzystwa Polskiej Młodzieży Ewangelickiej (TPME). Potwierdzeniem tego byl, np. artykuł autorstwa Artura Gansnera z kwietnia 1935 r. zamieszczony w „Zwiastunie Ewangelicznym”. Uznawał on liczbę dwóch towarzystw młodzieżowych, mieszczących się w dodatku w tym samym budynku przy placu Mirowskim za pozbawione sensu. Ponadto uważał, że ,z chwilą kiedy do stowarzyszenia może należeć każdy, kto tylko posiada małą maturę to po co taka organizacja, ani studencka, ani skupiająca wszystkich. «Filadelfia» deklasuje i rozbija społeczność, o której jedność tak się dopomina". Przeciwieństwem takich zachowań miało być, zdaniem Artura Gansnera, Towarzystwo Polskiej Młodzieży Ewangelickiej. Autor pisał na ten temat „My otwieramy drzwi naprawdę wszystkim, co nas ani gorszyć, ani smucić nie powinno. Trzeba tylko, aby jedni opuścili cokolwiek ze swych ambicji i miłości własnej na korzyść innych, którzy zyskują w ten sposób ogromnie" 35 . Żąania TPME nie mogły liczyć, ze zrozumiałych względów, na akceptację Stowarzyszenia Młodzieży Ewangelickiej „Filadelfii". Obie organizacje rozwijały swoje struktury nadal w sposób samodzielny.

"Filadelfia" bardzo często zmieniała swoje siedziby. Mieściła się m. in. na ulicy Szpitalnej $10 \mathrm{~m}$. 8, w zborze ewangelicko-reformowanym, potem na ul. Foksal 13, by na koniec otrzymać, dzięki poparciu ks. biskupa Juliusza Burschego bezpłatne pomieszczenie w nowo wybudowanym gmachu Towarzystwa Polskiej Młodzieży Ewangelickiej na placu Mirowskim $^{36}$. Wydatnej pomocy Stowarzyszeniu udzielał również prezes Kolegium Kościelnego Zboru Warszawskiego senator Józef Evert. „Stowarzyszenie Młodzieży Ewangelickiej „Filadelfia” zawdzięczało

\footnotetext{
${ }^{34}$ Ibidem.

${ }^{35}$ Ibidem, nr 14, 7 IV 1935, s. 112-113.

${ }^{36}$ Ibidem, nr 11, 17 III 1935, s. 83.
} 
mu uzyskanie kilkusetzłotowego funduszu dyspozycyjnego. Przeznaczono go na pomoc materialną dla mniej zamożnych studentów, członków Stowarzyszenia. Pożyczki udzielano na wniosek komisji opiniodawczej, w skład której wchodzili wice - prezes, kierownik sekcji religijno-etycznej oraz skarbnik ${ }^{37}$. Funkcję prezesów „Filadelfii” pełnili, m. in. wspomniani już: Eryk Hauptmann, Jerzy Cymorek, Adolf Schmidt oraz Ryszard Trenkler i Helmut Vogelsöng.

Członkami byli zarówno Polacy jak i Niemcy. Do Koła Studentów Ewangelików należał również Serbohużyczanin M. Nowak, który 26 lutego 1928 r. wygłosił w sali konfirmacyjnej Zboru Warszawskiego referat o Łużycach i o jego mieszkańcach ${ }^{38}$.

Członkowie „Filadelfii” starali się odznaczać wysokim morale. Podczas zaburzeń uczelnianych większość z nich nie zataiła swej mniejszościowej przynależności zajmując miejsca po lewych stronach audytoriów. Sąd koleżeński tylko w stosunku do dwóch członków wytoczył sprawy o zdjęcie odznak filadelfijskich.

Drugą organizacją grupującą ewangelicką młodzież akademicką stolicy było Koło Studentów Teologii Uniwersytetu Warszawskiego, grupujące słuchaczy Wydziału Teologii Ewangelickiej. Była to najstarsza organizacja studencka, powstała już w 1921 r. Grupowała studentów narodowości polskiej i niemieckiej. W roku 1933 otrzymała nowy statut, w którym główny nacisk położony na pokreślenie przede wszystkim jego naukowego charakteru oraz zaznaczając, że członkiem Koła może być tylko słuchacz zwyczajny Wydziału Teologii Ewangelickiej UW. Koło ogniskowało swą działalność przede wszystkim poprzez cotygodniowe zebrania, na których omawiano i rozważano różne kwestie natury naukowej i dogmatycznej związane ściśle z ich kierunkiem studiów. Koło posiadało również dobrze zaopatrzoną bibliotekę. W roku 1934 Koło liczyło 62 członków ${ }^{39}$. Dużo spośród nich należało jednocześnie do „Filadelfii”, udział ich jednak w tym gremium spadał, w roku 1937 sięgając 8\% ogólnej liczby członków tej organizacji.

W innych ośrodkach akademickich kraju powstawały też podobnego typu organizacje. W dniu 14 listopada 1926 w Poznaniu - w salce zbo-

${ }^{37}$ Ibidem, nr 20, 17 V 1936, s. 182.

${ }^{38}$ Ibidem, nr 12, 18 III 1928, s. 395.

${ }^{39}$ Ibidem, nr 48, 2 XII 1934, s. 381. 
rowej przy kościele staroluterskim na ul. Ogrodowej - powstało Stowarzyszenie Polskiej Akademickiej Młodzieży Ewangelickiej Uniwersytetu Poznańskiego (SPAME), wyłaniając się z istniejącego już wcześniej stowarzyszenia. W zebraniu założycielskim uczestniczyło około 20 osób. Członkami honorowymi wybrano: ks. Gustawa Manitiusa proboszcza parafii w Poznaniu i jednocześnie seniora diecezji pomorsko-wiekopolskiej oraz księży Karola Banszla, Karola Kotulę, profesorów Uniwersytetu Poznańskiego Namysłowskiego i Jonschera (prorektor) oraz nauczycieli gimnazjalnych Hauptamanna i Krzywonia ${ }^{40}$. Obrady prowadził Hauptmann. Pierwszym prezesem wybrany został student Jeske, zaś obowiązki kuratora organizacji zgodził się pełnić prof. Namysłowski. W swym wystapieniu programowym Jeske zaznaczył, że stowarzyszenie stara się o formalną legalizację swojej działalności oraz poinformowal, że w budynkach uniwersyteckich rozmieszono plakaty informujące o powstaniu stowarzyszenia. W planach działalności widział potrzebę organizowania odczytów oraz tzw. „imprez dochodowych". Zyski z tych ostatnich miały zostać przeznaczone na stworzenie funduszu pożyczkowego dla uboższych członków.

Stowarzyszenie odbywało swoje kolejne zebrania w mieszkaniach członków zboru poznańskiego, m. in. u Braunizów i Hauptmannów. Chcąc zdyscyplinować członków wprowadzono kary pieniężne za spóźnianie się na zebrania. Każdy, kto przyszedł na zebranie po 15 minutach od jego rozpoczęcia zobligowany był do wniesienia opłaty 50 groszy ${ }^{41}$.

Na kolejnym walnym zgromadzeniu w dniu 24 stycznia 1927 r., na wniosek studenta Roberta Fiszkala (w późniejszych latach duchowny Kościoła Ewangelicko-Augsburskiego), powołano do życia trzy sekcje: krajoznawczo-wycieczkowa, referatową i towarzyską.

$\mathrm{Na}$ jednym z zebrań Zarządu w roku 1928 student Renc zaproponował, żeby wysłać listy do wszystkich zborów ewangelickich w Polsce z prośbą o przysłanie nazwisk i krótkich życiorysów Polaków - ewangelików, którzy zasłużyli się szczególnie dla dobra kraju. Autor wniosku miał tu na myśli takie działania jak udział w powstaniach, na frontach wojennych lub na niwie społecznej. Zamysłem Renca było bowiem do-

\footnotetext{
${ }^{40}$ Ibidem, nr 16, 18 IV 1937, s. 146-147.

${ }^{41}$ Ibidem.
} 
prowadzenie do opublikowania na ten temat broszury. Wniosek został pomyślnie przyjęty. Wybrano nawet specjalną komisję mającą się zajmować tą sprawa. Nie została ona jednak zrealizowana w praktyce.

Stowarzyszenie nawiązało kontakt $\mathrm{z}$ innymi organizacjami studenckimi w kraju m. in. z „Filadelfią”. Założono również małą bibliotekę z czytelnią polskich pism kościelnych. Siedziba Stowarzyszenia miała swoją siedzibę na ul. Kossaka 18. Chcąc przybliżyć swoim członkom postać patrona ulicy, Stowarzyszenie zorganizowało szereg wycieczek, m. in. na wystawę prac malarskich Wojciecha Kossaka ${ }^{42}$.

Delegaci organizacji obecni byli na zjazdach młodzieży ewangelickiej. Utworzono również z czasem sekcję religijno-etyczną którą opiekował się ewangelicki kapelan Wojska Polskiego ks. kpt. Karol Edward Świtalski.

Stowarzyszenie Polskiej Akademickiej Młodzieży Ewangelickiej w roku akademickim 1929/1930 liczyło 50 członków. W kolejnym roku na jego czele stał student o nazwisku Macher. Pod jego kierownictwem zarząd obrał politykę integracji członków. Temu celowi miały służyć takie działania jak: urządzanie zebrań towarzyskich, referatowych oraz wycieczek. Nie przyniosło to chyba większych efektów, gdyż już w dniu 15 listopada 1931 roku wybrano nowe władze $\mathrm{z}$ niejakim Tekstorem na czele zarządu. Nowy zarząd podjąt, $m$. in. działania mające na celu zbliżenie ewangelickich studentów z miejscową parafią ewangelicko-augsburska. W dniu 29 listopada 1931 r. SPAME zorganizowało w tym celu „Informacyjne Zebranie Towarzyskie z Atrakcjami”. Referat wygłosił na nim prezes Koła Tekstor. W przemówieniu omówił, m. in. podstawy, cel oraz konieczność istnienia organizacji. Zachęcał również do wstępowania do niej. Na koniec spotkania, według relacji prasy „odbył się koncert solistów"43. Nowy zarząd SPAME podjął również działania na polu szerszej współpracy z innymi Kołami działającymi w Polsce. Chcąc usprawnić również pracę wewnętrzną stworzono trzy komisje: towarzyska, referatowa, wycieczkowa. Wszystkie projekty przygotowywane przez nie musiały uzyskać jednak aprobatę zarządu.

Pogłębiający się Wielki Kryzys przyhamował rozwój organizacji. Jej działalność ograniczała się jedynie do wyboru kolejnych władz. Na-

\footnotetext{
${ }^{42}$ Ibidem.

${ }^{43}$ Ibidem, nr 2, 10 I 1932, s. 15.
} 
stępne sześć lat przyniosły również zastój organizacyjny. Dopiero w dniu 8 marca 1936 r. wybrano nowy zarząd. Prezesem został Eugeniusz Maib, jego zastępcą Alfred Laube, sekretarzem Halina Keppe oraz skarbnikiem Artur Laube ${ }^{44}$. Na czele sekcji referatowej stanąl Wiktor Sommerfeld (od roku 1937/1938 prezes), a towarzyską pokierowała Maria Rodewaldówna ${ }^{45}$. Kuratorem $\mathrm{z}$ ramienia władz uniwersytetu został prorektor Jonscher.

We wrześniu 1928 r. powołano do życia w Krakowie dzięki pomocy prezesa „Filadelfii” Jerzego Cymorka, „Koło Ewangelików-Studentów Wyższych Uczelni”. Celem jego powstania było, jak głosił statut ,jednoczenie studentów ewangelików dla stworzenia braterskiego współżycia $\mathrm{w}$ duchu zasad i etyki ewangelickiej oraz świadczenie o prawdzie ewangelickiej wśród społeczeństwa polskiego"46. W październiku 1929 r. ich liczba wzrosła z początkowych 17 do 30 członków. W tym czasie organizowało ono, m. in. tzw. ,herbatki” z udziałem ks. proboszcza Niemczyka oraz parafian zboru krakowskiego, wycieczki po Krakowie i statkiem po Wiśle w stronę Bielan. Miesiąc później, w listopadzie $1929 \mathrm{r}$. na walnym zebraniu postanowiono zmienić nazwę organizacji na „Akademickie Koło Ewangelików Polaków w Krakowie”. W marcu 1930 r., wraz z Towarzystwem Młodzieży Ewangelickiej, zorganizowało ono zabawę karnawałową. Obecny był na niej ówczesny rektor Uniwersytetu Jagiellońskiego prof. dr H. Hoyer (nota bene ewangelik). W tym samym miesiącu udało się jeszcze urządzić „ostatki” oraz „wieczornicę Koła”. Na treść tego ostatniego złożyły się część muzykalne - wokalna, referat oraz część humorystyczna.

W następnych miesiącach zorganizowano ponadto zebranie na które zaproszono prof. Kubisza z Cieszyna ${ }^{47}$.

W dniu 30 września 1931 r powstała w Krakowie nowa organizacja: Ewangelicki Komitet Oświatowy. Powstał on z połączenia: Związku Ewangelików Polaków, Ewangelickiego Stowarzyszenia Państwowego, Towarzystwa Młodzieży Ewangelickiej oraz wspomnianego wyżej Akademickiego Koła Ewangelików Polaków. Za główne zadania Komitet

\footnotetext{
${ }^{44}$ Ibidem, nr 20, 17 V 1936, s. 190.

${ }^{45}$ Ibidem.

${ }^{46}$ Ibidem, nr 10, 9 III 1930, s. 75-76.

${ }^{47}$ Ibidem.
} 
postawił sobie „,zogniskowanie poczynań wszystkich towarzystw i rozbudzenie życia zborowego poprzez organizację zebrań odczytowych i skupienie w ten sposób wszystkich interesujących się życiem ewangelików w kraju i na świecie". Poza tym zorganizowano, m. in. cykl wykładów pt.: „Polacy-Ewangelicy zasłużeni Ojczyźnie”, przypominając, m. in. postać Jerzego Samuela Bandtkego ${ }^{48}$.

Stosunkowo późno, gdyż dopiero 22 listopada 1931 r. powstała organizacja studentów ewangelików na Uniwersytecie Jana Kazimierza we Lwowie. Tego dnia, przy udziale trzydziestu paru osób, utworzono tam Akademickie Koło Ewangelików-Polaków ${ }^{49}$.

Statut oparto na prawach obowiązujących w „Filadelfii”, Związku Studentów Inżynierii Polsko Lwowskiej i innych. Wybrano również pierwsze władze Koła. Prezesem został Gustaw Grubert. Jego zastępcą natomiast Józef Szeruda. Na pozostałe stanowiska wybrano: Jana Lorka (sekretarz), Karola Kiszkę (zastępca sekretarza), Erwina Kesselringa (skarbnik), Jerzego Iwanowa (zastępca skarbnika), Zofię Firlównę (bibliotekarz). Powołano również do życia Komisję Lustracyjna, którą tworzyli: P. Kleiber, Bronisława Heczkówna, Stanisław Erbert. Na straży przestrzegania norm i zasad moralnych stał Sąd Koleżeński w składzie: Alfred Ginsberg, Rudolf Köhli, Oskar Hess ${ }^{50}$.

Mimo, iż Łódź, poza Wolną Wszechnicą Polską nie posiadała ośrodka akademickiego to również i tam istniała studencka organizacja ewangelicka. Nosiła ona nazwę Koło Absolwentów i Studentów Ewangelików - Łodzian. Uchwaliło ono w dniu 8 IV 1936 r. przystapienie - na prawach suwerennej sekcji - do Stowarzyszenia Polskiej Młodzieży Ewangelickiej w Łodzi z pozostawieniem jednak obowiązującej dotychczas nazwy. Prezesem Koła wybrany został Stefan Knothe ${ }^{51}$.

Ewangelickie organizacje studenckie utrzymywały dość szerokie kontakty międzynarodowe np.: delegaci „Filadelfii” byli na międzynarodowych zjazdach młodzieży ewangelickiej. Zjazdy takie miały, m. in. miejsce w Anglii, Szwajcarii, Austrii i na Węgrzech. „Filadelfia” nawiązała również kontakt $\mathrm{z}$ Wszechświatową Federacją Chrześcijańskich

\footnotetext{
${ }^{48}$ Ibidem, nr 43, 25 X 1931, s. 334.

${ }^{49}$ Ibidem, nr 2, 10 I 1932, s. 15.

${ }^{50}$ Tbidem.

${ }^{51}$ Ibidem, nr 20, 17 V 1936, s. 190.
} 
Stowarzyszeń Studenckich, czego rezultatem była wizyta, jednego z jej przedstawicieli, sekretarza Chrześcijańskiego Związku Studentów w Holandii dr M. C. Slotemahera de Bruine. Odwiedził on Kraków, Lwów, Poznań, Warszawę zapoznając istniejące tam Koła z działalnością Federacji Genewskiej oraz nawiązując kontakt $\mathrm{z}$ akademicką młodzieżą w Polsce ${ }^{52}$.

W roku 1929 powstała jeszcze jedna organizacja, która grupowała wszystkie działające w tym czasie tego typu jednostki w. Polsce, o nazwie Zrzeszenie Akademickich Kół Ewangelickich w Polsce. Jej prezesem wybrano Jerzego Cymorka z Cieszyna ${ }^{53}$.

\section{Działalność wydawnicza}

Na przełomie lat dwudziestych i trzydziestych namiastką własnego organu prasowego był dodatek do warszawskiego tygodnika „Zwiastuna Ewangelicznego", noszący tytuł „Dla ewangelickich studentów”. Ukazywał się raz w miesiącu i skierowany był głównie do młodzieży

\footnotetext{
${ }^{52}$ Ibidem, nr 8, 25 II 1934, s. 55-56.

${ }^{53}$ Jerzy Cymorek pochodził z Zaolzia. Urodził się 31 VIII 1904 r. w Bystrzycy (powiat cieszyński, a od 1920 r. czesko-cieszyński). W latach 1925-1930 studiował teologię ewangelicką w Warszawie i w Bratysławie. W 1935 r. podjął pracę w polskim Kościele Ewangelicko-Augsburskim na Śląsku Zaolziańskim, gdzie objał najpierw urząd wikariusza w parafii w Ligotce Kameralnej (pow. czesko-cieszyński). Na tym stanowisku pracowal do 1938 r. Po powrocie Zaolzia do Polski zostal wybrany II proboszczem luterańskiej parafii w Czeskim Cieszynie (zwanym od X 1938 r. Cieszynem Zachodnim). Pozostał na tym stanowisku do wybuchu wojny, kiedy to zostal pozbawiony przez hitlerowców możliwości pracy w Kościele. Przez cały okres wojny pracował fizycznie (m. in. w kuźni w Bystrzycy). Przez pierwsze miesiące po wyzwoleniu był administratorem parafii w Wiśle, a następnie w zaolziańskim Trzyńcu i Czeskim Cieszynie. W roku 1952 zwierzchnik polskich luteran ks. superintendent Józef Berger został zmuszony przez władze czeskie do opuszczenia Zaolzia i przeniesienia się do Bratysławy (jego rodzina mieszka tam do dziś). W związku z zaistniałą sytuacją powstała potrzeba wyboru nowych władz. Nowym superintendentem (od 1956 r. biskupem) Śląskiego Kościoła Ewangelickiego Augsburskiego Wyznania w Czechosłowacji został Jerzy Cymorek. Urząd ten pełnił, przez trzy kadencje. Ostatnią przerwała nagła śmierć w dniu 8 II 1971 r. w Czeskim Cieszynie, [w:] J. Szturc, Ewangelicy w Polsce Slownik biograficzny XVI-XX w., Bielsko - Biała 1998, s. 57-58.
} 
akademickiej stolicy. Jego redaktorem została Irena Wieczorkówna. W dobie Wielkiego Kryzysu redakcja nie była jednak w stanie utrzymać na dłuższą metę tego dodatku. W związku z tym na początku lat 30-tych przerwano jego wydawanie. Jednak ideę powołania własnego pisma środowisko ewangelickich studentów nadal kultywowało. Udało się to dopiero urzeczywistnić w drugiej połowie lat trzydziestych.

Od 11 grudnia 1937 r. w Warszawie rozpoczęto wydawanie kwartalnika zatytułowanego „Filadelfia”. W podtytule dodano ponadto, że jest to „,Organ młodzieży ewangelickiej”. Od nr 2 z marcu 1939 r. podtytuł uległ zmianie i odtąd aż do wybuchu wojny brzmiał „Ogólnopolski organ studentów ewangelików”. Pismo wydawał Komitet Redakcyjny Zarządu Stowarzyszenia Młodzieży Ewangelickiej „Filadelfia” oraz Koło Studentów Ewangelików „Filadelfia”. W skład kolegium redakcyjnego weszli Juliusz Dietz (późniejszy duchowny Kościoła Ewangelicko-Augsburskiego), Jerzy Markwart oraz od 1938 r. Gustaw Meyer.

Funkcję redaktora pełnił początkowo Jan Niewieczerzał (po II wojnie światowej ksiądz Kościoła Ewangelicko - Reformowanego), a od 1939 r. Zbigniew Grad. Z kolei redaktorem odpowiedzialnym został Helmut Vogelsöng.

Siedziba redakcji mieściła się na Placu Mirowskim 4, skąd gotowy materiał wysyłany był pierwotnie do Drukarni Poznańskiej. Następne numery drukowane były w Zakładach Graficznych P. Szwedy (ul. Warecka 9, Warszawa). Ostatnią drukarnią wydająca „Filadelfię” została przed wrześniem 1939 r. firma „Stero” Baum i Wolfram (ul. Elektoralna 10, Warszawa). Kwartalnik miał stosunkowo wysoki nakład. Wynosił on np. w okresie czerwiec - sierpień 1938 r. 600 egzemplarzy. Pismo można było abonować przez cały rok. Wtedy całkowity koszt prenumeraty wynosił 1 zł 20 groszy. Natomiast numer pojedynczy kosztował 30 groszy $^{54}$. Prenumeratorzy nie zyskiwali w związku z tym jakiejkolwiek ulgi przy zamówieniu rocznym.

Myśl wydawania własnego pisma kiełkowała w umysłach działaczy „Filadelfii” od samego początku działalności tej organizacji studenckiej czyli od 1932 r. Stało się to jednak możliwe dopiero pięć lat później.

${ }_{54}$ J. Kłaczkow, Czasopiśmiennictwo protestanckie w Polsce w latach 1918-1939, Toruń 2003, s. 288-289. 
Nazwa pisma brzmiała tak samo jak organizacja je wydająca. W numerze pierwszym z grudnia $1938 \mathrm{r}$. w następujący sposób wythumaczono fakt powstania kwartalnika: „Wydajemy pierwszy numer pisma pod nazwą „Filadelfia”, które jest organem młodzieży ewangelickiej. Wychodzimy z założenia, że młodzież ewangelicka winna posiadać własne pismo, w którym mogłaby wypowiadać swoje zdania i kreślić śmiałe plany na przyszłość. Do współpracy zapraszamy wszystkich, chcemy, aby każdy ewangelik, który czuje po polsku i którego sercu jest droga młodzież, wyciagnął rękę i kroczył z nami naprzód z myślą o lepszym jutrze naszego Kościoła i Państwa. Chcemy zerwać z ospałością i gnuśnościa, i rzetelnie pracować dla polskiego ewangelicyzmu". W numerze znalazł się również tekst przemówienia programowego prezesa Stowarzyszenia Młodzieży Ewangelickiej „Filadelfia” Helmuta Vogelsönga zatytułowany „Na nową drogę”.

Kwartalnik wydawany był z myślą głównie o studiujących w stolicy luteranach oraz kalwinistach. W redakcji dominowali jednak głównie członkowie Kościoła Ewangelicko-Augsburskiego. Oni dominowali zresztą również wśród studiującej młodzieży.

Treść „Filadelfii” miała charakter biblijno-informacyjny. Zawierała rozmyślania oparte na wybranych wersetach Pisma Św., kazania, m.in. ks. prof. Rudolfa Kesselringa. W dalszej części dawano wspomnienia znanych działaczy Kościoła, np. ks. prof. Józefa Szerudy z pracy wśród młodzieży oraz historię działających organizacji ewangelickich, np.: Koła Teologów Ewangelickich Studentów Uniwersytetu Józefa Piłsudskiego w Warszawie, „Filadelfii”, itd. Już od pierwszego numeru w piśmie znajdowały się różnego typu odezwy, nawołujące do abonowania i kupowania gazety. Zwracano się szczególnie do absolwentów i byłych filadelfistów, prosząc ich na łamach o nadsyłanie swoich adresów. Nie odniosło to spodziewanego efektu. Wpływy z prenumeraty były tak niskie, że starczały jedynie na pokrycie kosztów papieru, druku oraz przesyłki pocztowej (nr 3, IX - XI 1938, s. 7).

Od numeru drugiego (marzec - maj 1939) zmieniono podtytuł. Wynikało to ze zmiany nazwy Stowarzyszenia Młodzieży Ewangelickiej „Filadelfia" na Koło Studentów Ewangelików. Wymogła to nowa ustawa o stowarzyszeniach akademickich. Na wydawanie pisma musiał się zgodzić rektor danej uczelni. Wprowadzone modyfikacje spowodowały powołanie nowego redaktora. Został nim wspomniany już wcześniej 
Zbigniew Grad. Kwartalnik odnotował w następujący sposób zmiany: „Kierowała nami chęć stworzenia czasopisma o wyłącznie akademickim charakterze stanowiącym trybunę przeznaczoną do poruszania $\mathrm{w}$ niej kwestii związanych z naszym życiem duchowym i organizacyjnym"ss.

Wprowadzone zmiany nie wyszły na dobre jego dotychczasowemu obliczu ideowemu, które charakteryzowało się dotychczas stosunkową bezstronnością. „Filadelfia” zaczęła bowiem poruszać bardzo nośne wśród części ówczesnych studentów tematy. Koncentrowały się one zaś głównie w tym czasie na problemach „czystości” oraz wyższości danej rasy.

Znalazło to swoje odzwierciedlenie w jednym $\mathrm{z}$ artykułów ewidentnie pisanych z pozycji nacjonalistycznych. Znalazły się tam, m. in. następujące fragmenty: „Rasa powinna reprodukować swe najlepsze elementy, powinna przeciwstawić się wytwarzaniu jednostek niskich [...]". Zgodnie też z panującą wówczas modą na stosowanie tzw. inżynierii społecznej postulowano, aby „Potomstwo ludzi bogatych i zbrodniarzy było od najmłodszych lat oddzielone od swego środowiska, ażeby bezczynność, brak odpowiedzialności i dyscypliny moralnej nie niweczyły ich wartości odziedziczonych. [...] Społeczeństwo musi się chronić przed jednostkami, które swoje środowisko na nowo zaczną zatruwać"s6.

Cytowane fragmenty ukazują ferment ideowy wśród przyszłych elit kraju. Hasła nacjonalizmu i rasizmu tak popularne w ówczesnej Europie nie ograniczały się jedynie do tych studentów, którzy nosili w klapach marynarek „mieczyk Chrobrego”. Prąd ten ogarniał również studentów protestanckich. Było to po części efektem ich pochodzenia narodowego. Większość $\mathrm{z}$ nich dorastała $\mathrm{w}$ bardzo patriotycznie nastawionych rodzinach, gdzie kult polskości był szczególnie silny. Ich rodzice wychowywali się pod wpływami ideologii tzw. ,polskiego ewangelicyzmu", która zakładała, ze względów narodowych, m. in. polonizację niemieckiej części Kościoła Ewangelicko - Augsburskiego. Polonizatorami byli zaś w przeważającej większości potomkowie przybyszy z Niemiec. Nic dziwnego, że na tak przygotowanym, trochę neofickim,

55 „Filadelfia” nr 2; III - V 1939.

${ }^{56}$ Ibidem. 
gruncie rodziły się wśród sporej grupy ewangelickich studentów silne prądy narodowe. Powstawał nawet pewien typ poglądów politycznych bardzo zbliżonych do programu endecji lat 30-tych. Większość członków, np. „Filadelfii” czuła się w sensie politycznym państwowcami oraz narodowcami o poglądach zbliżonych do środowisk prawego skrzydła sanacji. Jedynymi czynnikami odróżniającymi ich od endeków były konfesja oraz stosunek do obozu rządowego. Te różnice okazały się jednak przeszkodami nie do pokonania. Dla pozostałego środowiska akademickiego pozostawali w związku $\mathrm{z}$ tym pewnym typem studenckiego folkloru działającym jedynie we własnym gronie.

Spadek wpływów protestanckich wśród młodzieży akademickiej był zauważany również przez niektórych publicystów protestanckich, $\mathrm{m}$. in. Czesław Lechickiego (nota bene konwertyty z rzymskiego katolicy$\mathrm{zmu}$ ). W jednym $\mathrm{z}$ jego licznych tekstów zamieszczanych głównie w stołecznym ,Zwiastunie...” można było przeczytać, m. in.: „[...] wśród młodzieży, gdzie jeszcze 10 lat temu owocnie pracował Chrześcijański Związek Akademików, wpływy protestanckie spadły do zera. O jakichkolwiek ambicjach ekspansjonistycznych, o widokach misyjnych, o odrodzeniu idei reformacyjnych Kościoła narodowego, mowy w obecnych warunkach nie ma"s7.

Plany środowisk polsko - ewangelickich były bowiem we wcześniejszych latach bardzo ambitne. Credem tego stały się słowa proboszcza luterańskiej parafii św. Trójcy w Warszawie ks. Zygmunta Michelisa wygłoszone w kwietniu 1935 r. do członków Towarzystwa Polskiej Młodzieży Ewangelickiej. Mówił w nim, m. in. „Dmijcie w trąby i bijcie w bębny, werbując młodzież pod swoje sztandary, zajmijcie ich zabawą i sportem, ale niech to będzie wszystko środkiem do celu. Do jakiego celu? Macie go wyraźnie napisany na waszym sztandarze: „Polska" i „Ewangelicka" - zestawienie będące hasłem, a może naszym przyszłym programem, a na pewno nie rzeczywistością i życiem. „Polska” na pierwszym miejscu. Nie dlatego, aby to było zadaniem ważniejszym lecz dlatego, że jest łatwiejszym. Wszyscy wokoło jesteśmy i chcemy być Polakami. Dziś polskość nie jest walką lecz chwałą. Ale dlatego dziś też do polskości nie wystarcza jej hasło i wyznanie, trzeba ją wy-

${ }^{57}$ Protestantyzm na wygnaniu, [w:] „Zwiastun Ewangeliczny” nr 1, 2 I 1938, s. 3. 
pełnić treścią $i$ to nie narodową, bo wszak jest już wolna, a więc świadomą, lecz treścią duchową i moralną. I dlatego przede wszystkim „Ewangelicka”. A to jest zadanie trudne. Bo trzeba być innym, aniżeli otoczenie. A to znów w podwójnym znaczeniu wyznaniowym i moralnym. Nie brak Polsce Polaków, lecz brak jej Polaków szlachetnych, ofiarnych, uczciwych, chrześcijańskich z ducha i życia. Ach gdybyśmy mieli prawo powiedzieć: Polaków ewangelików. Takich Polaków niech wychowuje w szeregach TPME w Warszawie w nowych lepszych warunkach swego organizacyjnego bytowania. A do tego trzeba żywego prądu ducha. A ten tworzy się tylko w uregulowanych brzegach, w wąskim korycie"s8.

Druga połowa lat trzydziestych przyniosła jednak załamanie jakichkolwiek prób propagowania idei ewangelickich na wyższych uczelniach.

Umysły studenckie w tym czasie w ogromnej większości myślami były już zupełnie gdzie indziej. Czynnik religijny liczył się mniej, niż przeżycia w stylu ,marszu na Kowno” czy egzekwowanie wobec żydowskich kolegów getta ławkowego. Polityka i emocje z nią związane brały zdecydowanie górę i dominowały w poglądach większości przyszłych inteligentów aż do wybuchu II wojny światowej.

58 „Zwiastun Ewangeliczny” nr 14, 7 IV 1935, s. 105. 